\title{
CHICK LIT DALAM DUNIA SASTRA INDONESIA
}

\author{
Kasno \\ Fakultas Sastra, Universitas Nasional \\ Pos el: ksnoas@yahoo.com \\ HP: 0817767736 \\ Erlis Nur Mujiningsih \\ Pos el: erlis2006@yahoo.co.id \\ HP: 08129193646
}

\begin{abstract}
ABSTRAK
Chick lit merupakan sejenis karya sastra yang ditujukan untuk wanita muda, lajang, dan mandiri seperti slogan yang tercetak pada sampul depan luar. Untuk mengetahui lebih mendalam tentang chick lit, penelitian ini bertujuan untuk mendeskrepsikan ikhwal chick lit dalam dunia sastra Indonesia. Penelitian ini menggunakan metode deskripsi kualitatif. Hal ini dilakukan untuk membantu pembaca mengetahui apa yang terjadi di lingkungan, di bawah pengamatan, seperti apapandangan partisipan, peristiwa, dan aktivitas yang terjadi dalam latar penelitian. Teori yang diacu dalam kajian ini adalah teori estetika resepsi Segers, yang menyatakan bahwa estetika resepsi melihat nilai sastra sebagai sebuah konsep dari perubahan yang tetap bergantung pada sistem norma pembacanya. Analisis dilakukan untuk memaparkan sejarah kemunculan chick lit, gaya pengarang, dan respons pembaca Indonesia terhadapchick lit. Kesimpulannya adalah novel-novel yang dikelompokkan sebagai chick lit ditulis oleh perempuan dan ditujukan kepada pembaca perempuan. Pembaca novel-novel tersebut memang sebagian besar adalah perempuan, baik perempuan yang sudah matang usianya maupun perempuan-perempuan muda yang dapat digolongkan sebagai pembaca pemula.
\end{abstract}

Kata kunci: karya sastra, gaya pengarang, perempuan, pembaca pemula

\section{ABSTRACT}

Chick lit is a kind of literary works aimed at independent single young women is like the slogan printed on the outside front cover. To learn more about chick lit, this study aims to describe the beginning of chick lit in the world of Indonesian literature. This study uses a qualitative description to give an aid for the readers to know what is happening in the environment, under observation, such as what the participants' point of views, events and activities occuring in the setting. Theory referenced in this study is the theory of Seger' reception aesthetics, which states that the aesthetic reception views the value of literature as a concept of constant change depending on the system of readers' norms. The analysis conducted to describe the history of the emergence of chick lit, the style of the author (authorship), and Indonesian readers' response. The conclusion is that novels classified as chick lit written by women and aimed at female readers. Readers of the novels are indeed mostly women, both women of mature aged and those who can be classified as beginner readers.

Keywords: literature, style of the authors, women, beginner reader 


\section{PENDAHULUAN}

\section{Latar Belakang}

Chick Literature atau sering disingkat dengan chick lit dalam dunia sastra Indonesia masih merupakan hal yang baru. Chick lit muncul dan berkembang di Inggris dan Amerika. Di Indonesia jenis karya ini baru muncul dan berkembang sekitar tahun 2000-an. Kemunculan chick lit di Indonesia diawali dengan karya-karya terjemahan, kemudian pada tahun 2003 muncul karya lokal.

Chick lit merupakan sejenis karya sastra yang ditujukan untuk wanita muda, lajang dan mandiri seperti slogan yang tercetak pada sampul depan luar. Chick lit yaitu "being single and happy" dan pada sampul depan dalam yakni target pembacanya dipaparkan sebagai "para wanita muda yang cerdas, mandiri, berani, jujur pada diri sendiri. Selain itu, ditampilkan wanita kosmopolitan yang umumnya masih lajang, punya karier, dan bergelut dengan berbagai masalah kehidupan modern”.

Salah satu ciri chick lit penekanannya adalah pada kelajangan dan menikmati kelajangannya itu. Adapun ciri yang lain, tema tidak berkutat pada masalah percintaan saja, walaupun tetap ada. Selain itu, lebih banyak dimunculkan permasalahan persahabatan dan persoalan di kantor atau masalah dengan orang tua.

Selain ciri tersebut, chick lit juga ditandai adanya ciri fisik. Warna sampul depan berbeda dengan karya sastra lain. Warna sampul meriah, seperti warna merah, pink, hijau, biru. Gambar sampulnya berjenis komikal. 
Ciri yang lain adalah kedekatan mereka dengan dunia film atau audiovisual.Ada beberapa di antara karya-karya tersebut yang dilengkapi dengan vcd. Selain itu, ada beberapa karya yang berasal dari film layar lebar, seperti Brownies atau dari karya ke film layar lebar. Sebagai bagian dari karya sastra populer, karya-karya tersebut banyak yang dapat mencapai best seller. Karya-karya tersebut juga ditandai dengan pemakaian bahasa "gaul" termasuk di dalamnya pemakaian judul-judul dalam bahasa Inggris.

Chick lit mendapat tanggapan yang luar biasa dari pembacanya. Hal tersebut terbukti dengan diadakannya sayembara naskah penulisan chick lit. Dalam hal ini penerbit terlihat memburu naskah. Kenyataan tersebut membuktikan bahwa kehadiran jenis karya chick lit ini memang perlu diteliti lebih lanjut, terutama mengenai gaya pengungkapannya dan respons pembacanya. Penelitian tentang chick lit belum banyak dilakukan. Salah satu penelitian yang pernah dilakukan terhadap chick lit dilakukan oleh Jenny M. Junjungan dari Universitas Petra Surabaya dengan judul "Membaca Novel Populer Wanita: Romance dan Chick Lit'”.

\section{Rumusan Masalah}

Berdasarkan latar belakang di atas masalah yang akan dibahas adalah sebagai berikut.

1. Bagaimana Sejarah Kemunculan chick lit. 
2. Bagaimana gaya pengungkapan pengarang dalam chick lit.

3. Bagaimana respons pembaca Indonesia terhadap kehadiran chick lit.

\section{Tujuan Penulisan}

Tujuan penelitian ini adalah sbagai berikut.

1. Untuk mengetahui sejarah iemunculan chick lit.

2. Untuk mengetahuigaya pengungkapan pengarang dalam chick lit.

3. Untuk mengetahui respons pembaca Indonesia terhadap kehadiran chick lit.

\section{KAJIAN PUSTAKA}

Karya sastra merupakan struktur estetik yang terdiri atas tanda-tanda estetik yang dipancarkan kepada pembacanya. Oleh karena itu, dapat dikatakan bahwa estetika resepsi adalah sebuah pendekatan dengan dititikberatkan pada peranan pembaca yang memperhatikan karya sastra sebagai sebuah struktur. Karya sastra sebagai sebuah struktur menentang struktur karya sebelumnya. Estetika resepsi melihat nilai sastra sebagai sebuah konsep dari perubahan yang tetap bergantung pada sistem norma pembacanya (Segers, 1978:49). Pendekatan estetika resepsi merupakan sebuah kejutan untuk evaluasi kesusastraan untuk melengkapi perbedaan pandangan dari konsep "nilai kesusastraan”. Hal tersebut disebabkan selama ini pendekatan secara objektif menganggap bahwa nilai sastra terlepas dari pembacanya (Segers, 1978: 49). 
Dilihat dari sisi lain, karya sastra bukan merupakan sebuah objek yang berdiri sendiri dan memiliki wajah yang sama pada setiap pembaca pada masing-masing periode. Karya sastra bukan merupakan sebuah monumen yang tidak memiliki rival di dalam pembicaraannya. Karya sastra lebih menyerupai sebuah orkestrasi yang selalu menampilkan paduan nada baru bagi pembacanya. Pembaca bebas untuk menyubsitusikan kata-kata di dalam karya sastra dan membuat makna yang banyak pada waktu yang sama. Kata-kata di dalam karya sastra merupakan suatu kreasi yang dilakukan pengarangnya, misalnya dengan perubahan urutan untuk mengenakan pendengaran. Karya sastra harus dimengerti sebagai sebuah kreasi suatu dialog, dan filologi telah menemukan kembali keberlangsungan pembacaan sebuah teks dan tidak berhenti hanya sebagai fakta belaka ( Jauss, 1975: 12—13; Pradopo 1986: 185 ).

Berkaitan dengan paparan di atas, para ahli sejarah sastra, ahli estetika, dan kritikus berpendapat tidak ada satu pun sebuah nilai yang benar sebab tidak terdapat nilai estetika yang benar sehingga tidak ada sebuah evaluasi saja. Jadi, estetika resepsi sebagai sebuah pendekatan melihat karya sastra sebagai objek estetik yang memiliki keragaman nilai dalam perkembangan nilai-nilai estetiknya. Sementara itu, karya sastra juga merupakan sebuah objek estetik yang menciptakan dialog dengan pembacanya sesuai dengan sifatnya yang banyak tafsir. Di dalam hal ini estetika resepsi menempatkan karya sastra sebagai bagian perkembangan struktur. Estetika resepsi merupakan salah satu titik tolak dari perkembangan sejarah sastra dengan tidak mengabaikan struktur dalamnya. 
Objek estetik hanya dapat ditentukan dalam satu jalan: pembicaraan tentangnya. Jadi, sangatlah penting untuk menemukan dan menyistemkan reaksi pembaca di dalam jalan yang dibenarkan (Segers, 1978:52). Demikian pula di dalam karya sastra, peranan pembaca sangat penting untuk dapat menemukan nilai-nilai di dalam karya sastra yang selalu berada dalam perubahan yang teratur. Oleh karena itu, sistematika reaksi pembaca terhadap suatu karya sastra dapat memasukkan dan menempatkan karya sastra di dalam tatanan kesusastraannya. Penentuan dan penempatan karya sastra ke dalam tatanan kesusastraannya itu tidak terlepas dari norma sastra yang melingkupinya yakni dari sejarah perkembangan sastra dan lingkungan sosialnya. Hal tersebut dilakukan dengan bertitik tolak dari tanggapan terhadap struktur karya sastra itu sendiri.

Di dalam penerapan metode estetika resepsi ini yang menjadi perhatian utama adalah tanggapan pembaca. Tanggapan pembaca tersebut bermacam-macam ragamnya. Tanggapan pembaca pada dasarnya dibagi dalam dua bagian, yaitu tanggapan dalam satu periode dan tanggapan dari beberapa periode secara berurutan. Segers (1978:45) menyatakan bahwa penelitian terhadap objek estetik dapat dibagi dalam dua kategori: penelitian di dalam sejarah reaksi pembaca dan di dalam zaman pembacanya atau dengan kata lain penelitian secara diakronis dan sinkronis.

Sementara itu, untuk memilah jenis tanggapan digunakan pembagian empat sudut pandang yang dikemukakan oleh Abrams (dalam Teeuw, 1988: 49-50) Pada dasarnya analisis terhadap sebuah karya sastra dibagi dalam empat sudut pandang, yaitu mimetik, 
ekspresif, pragmatik, dan objektif. Sudut pandang mimetik dipakai berdasarkan pandangan bahwa karya sastra merupakan sebuah tiruan, bayangan atau gambaran mengenai dunia dan kehidupan manusia. Kriteria utama pendekatan ini adalah kebenaran dari apa yang digambarkan (mimetik). Kedua, sudut pandang ekspresif berdasarkan anggapan bahwa karya sastra merupakan ekspresi atau limpahan atau ungkapan perasaan hasil imajinasi pengarang yang dilakukan melalui tanggapan, pemikiran, dan perasaannya. Ketiga, sudut pandang pragmatik yang berdasarkan pandangan bahwa karya sastra adalah sesuatu yang disusun supaya dapat mencapai pengaruh tertentu pada pembacanya. Keempat, sudut pandang objektif yang berdasarkan pandangan bahwa karya sastra adalah sesuatu yang bebas dari pengarang, pembaca, dan alam sekitarnya. Oleh karena itu, tanggapan pembaca yang akan dipaparkan berikut ini akan dipilah-pilah berdasarkan keempat dasar pendekatan di atas.

\section{Istilah dan Arti}

Dunia perbukuan di Indonesia beberapa tahun terakhir ini digemparkan oleh munculnya karya-karya penulis muda yang sering disebut sebagai chik lit yang kemudian diikuti oleh teen lit dan lit lit lainnya. Gegap gempita dunia perbukuan di Indonesia tersebut menggembirakan, tetapi sekaligus mencemaskan. Menggembirakan karena kaum muda mulai menyenangi membaca buku, terutama para gadisnya. Mencemaskan dengan alasan apakah para remaja tersebut hanya akan berhenti saja sampai membaca chick lit dan teen- 
lit. Apakah budaya membaca saat ini yang nge-trend akan terus berlanjut? Kita berharap semuanya akan terus berlanjut. Harapan kita chick lit dan lit lit yang lain itu akan menjadi semacam "jembatan" bagi publik perbukuan Indonesia untuk menjadikan masyarakat Indonesia menjadi sebuah masyarakat tradisi membaca dan bukan lagi masyarakat dengan tradisi lisan saja. Sebagaimana dikeluhkan oleh para cendikia selama ini.

"Chick Literature" (disingkat chick lit) yang didefinisikan sebagai "literary genre that features books written by women and focusing on young, quirky, female protagonists" (Wordspy.com). Chik lit disebutkan oleh Satmoko (2005: 2) sebagai sebuah karya sastra yang bersifat popular. Selain itu, secara fisik bahan bacaan ini tampil dengan tanda yang mencolok. Di sampul depan terpampang label chik lit. Sampul depannya pun khas bergaya vector-art dengan warna-warna pastel dan khusus untuk chik lit Indonesia sering judulnya memakai bahasa Inggris atau bahasa yang dipakai dekat dengan pembaca (gue banget), misalnya, Cintapucinno atau Cewe Matre.

Secara ringkas chik lit dapat disebut sebagai bacaan perempuan. Istilah chik lit muncul dari sebutan slang untuk perempuan muda, chick-ayam betina. Namun, juga dikaitkan dengan referensi derivatif untuk chiklet, sebuah merek permen karet, dengan implikasi bahwa buku ini ringan seperti mengunyah permen karet .(Tempo, 6 Februari 2005). Oleh karena itu, bacaan ini tergolong bacaan yang easy reading. Orang tidak harus berkerut membacanya, tidak perlu mengalokasikan waktu khsusus karena bias dibaca kapan saja (Tempo, 6 Februari 2005). 
Chick lit berasal dari singkatan chiken literature. Kata chicken yang dipakai diturunkan dari kata yang menunjuk ke anak ayam. Seekor anak ayam yang meminta orang-orang yang melihatnya untuk selalu menyanyanginya (Goodman, 2005). Bahan bacaan ini memang ditandai secara khas oleh tokoh utamanya yang seorang perempuan lajang, perempuan lajang manis yang memanggil untuk selalu disayangi. Chick Lit menurut Hula Hoops sebagaimana dikutip oleh Benny Chandra (2004) adalah karya sastra kontomporer untuk perempuan. Genre ini merupakan evolusi dari novel-novel roman standar. Tokoh utamanya secara umum digambarkan sebagai sebuah karakter yang realitas yang mencoba untuk merefleksikan masalah dan ambisi sehari-hari seorang perempuan dan laki-laki di dalam dunia yang kompleks dan berusaha menemukan cinta dalam sebuah masyarakat modern. Bahwa chick lit dekat dengan kehidupan masyarakat modern juga dinyatakan oleh Scarleet Thomas (2002) yang menyatakan bahwa chick lit adalah sejenis karya yang mencoba untuk mengembalikan dunia nyata ke dalam sebuah karya sastra.

Chick lit menunjuk ke sejenis karya sastra modern untuk perempuan juga disampaikan oleh kelompok chick lit USA. Chick lit memang menggambarkan kehidupan perempuan lajang berumur 20-30 tahunan yang sedang mencari pasangan yang sempurna. Chick lit atau kadangkala disebut juga chic fic memberikan sudut pandang baru pada hubungan kemanusiaan perempuan itu dan humor untuk kehidupan perempuan lajang itu. Buku ini dapat ditemukan sebagai sebuah buku yang lucu, cerdas, menyenangkan, dan melegakan. Karya-karya yang digolongkan ke dalam genre ini memfokuskan diri pada 
kehidupan perempuan berumur antara 20-30 tahun saat perempuan ini harus mengambil keputusan untuk hidupnya dalam rangka mencari pasangan yang tepat, pekerjaan yang tepat, dan segala sesuatu mengenai masa depannya yang akan menentukan kualitas kehidupannya di kemudian hari.

Chick lit adalah sebuah karya yang bersifat modern, penuh gaya, tajam, terus terang, dan sangat berani mengungkapkan perjuangan para perempuan lajang (chick) Karya ini juga penuh dengan pengalaman seksualitas, sensual serta liar yang sering memberi kejutan-kejutan tertentu kepada pembacanya (Diane Goodman). Pada chick lit tokohtokohnya diberi keberanian untuk mengungkapkan semua permasalahannya tanpa harus merasa takut untuk dicap dengan berbagai stempel yang memojokkannya, seperti dicap hedonis atau korban mode. Demikianlah chick lit atau juga sering dituliskan chick-lit merupakan sejenis bacaan yang ditulis oleh perempuan dan ditujukan untuk perempuan dan isinya mengenai perjuangan perempuan lajang, obsesi-obsesinya untuk berumah tangga di tengah kehidupan modern yang menjeratnya.

Di Indonesia chick lit menjadi semacam mode dan masuk menjadi gaya hidup perempuan muda. Apabila di tempat asalnya, tidak ada pelabelan khusus terhadap karyakarya sejenis tersebut, di Indonesia pelabelan dimunculkan. Seperti diakui oleh sebuah penerbit. /Label Chick lit sebenarnya sudah ada dari luar negeri. Namun, di sana, bukubuku itu tidak dipasang label. Kami memutuskan memasang label chick lit karena sesuai dengan pasar Indonesia dan agar lebih menarik. Ternyata cukup berhasil, Bahkan label lain 
muncul seperti lajang kota yang dipakai untuk mememberi label novel-novel karya Albertine Endah atau label Metropop, karya sejenis yang ditujukan untuk pria dan wanita. Namun, label lajang tidak sepenuhnya disukai oleh penulis lain, Icha Rahmawati misalnya, salah seorang penulis chick lit lebih nyaman dengan definisi chick lit sebagai teman bagi pembaca yang ditujukan sebagai tempat berbagi pengalaman dan pemikiran, seperti diakuinya saat acara jumpa pembaca di Depok, UI. Yang menarik, di Indonesia selain chick lit juga muncul turunannya yaitu teen lit, bacaan yang ditujukan untuk para remaja. Sebelumnya jenis bacaan serupa ini sudah ada dengan tokohnya sendiri-sendiri. Dapat dikatakan bahwa jenis bacaan ini hampir ada di setiap zaman dengan trend yang berbedabeda.

Keistimewaan lain yang dimiliki chick lit adalah kedekatannya dengan dunia film. Entah itu chick lit yang kemudian menjadi film, seperti novel Bridget Jone's Diary yang sukses kemudian difilmkan dengan judul yang sama dan mencapai box office. Di Indonesia selain ada chick lit sukses, seperti Cintapucinno yang kemudian difilmkan, juga ada film yang sukses kemudian dijadikan novel, seperti film 30 Hari Mencari Cinta yang sukses ditulis menjadi sebuah novel oleh Nova Riyanti Yusuf. Hal tersebut dilakukan dengan asumsi segmen penonton film sama dengan segmen pembaca chick lit dan teen lit (Tempo, 6 Februari 2005). 


\section{METODE PENELITIAN}

Di dalam penelitian ini digunakan salah satu metode penelitian yaitu deskripsi kualitatif. Penelitian deskripsi kualitatif ini adalah untuk membantu pembaca mengetahui apa yang terjadi di lingkungan di bawah pengamatan, seperti apa pandangan partisipan yang berada di latar penelitian, dan seperi apa peristiwa atau aktivitas yang terjadi di latar penelitian. Dengan demikian, Deskripsi yang cukup dan pertanyaan langsung harus dimasukkan untuk membantu pembaca memahami secara penuh latar penelitian dan pemikiran orang yang terwakili dalam naratif (Emzir, 2008: 174-175).

Hal di atas dimaksudkan agar data-data yang ada dapat memberikan gambaran yang tepat dari suatu gejala dan pokok permasalahan secara kualitas dapat dipaparkan secara rinci dan mendalam.

\section{Data dan Sumber Data}

Data yang dimaksud dalam penelitian ini adalah tanggapan kritikus sastra dan bukan kritikus sastra dimulai pada saat kemunculan chick lit yaitu secara acak pada tahun 2000 sampai 2005. Adapun sumber data penelitian ini adalah majalah, surat kabar, buku, dan hasil tanggapan yang ada di internet. 


\section{Teknik Pengumpulan Data}

Pengumpulan data dalam penelitian ii digunakan pendekatan estetika resepsi. Secara operasional, pendekatan ini melakukan langkah-langkah kerja sebagai berikut.

1) Merekonstruksi bermacam-macam konkretisasi sebuah karya sastra dalam masa sejarahnya;

2) Meneliti hubungan di antara konkretisasi; dan

3) meneliti hubungan karya sastra dengan konteks historis konkretisasi.

\section{HASIL DAN PEMBAHASAN}

\section{Sejarah dan Kemunculannya}

Chick lit mulai populer sekitar tahun 1997. Novel novel ini ditulis oleh wanita dan ditujukan secara eksklusif untuk pembaca wanita. Di negara asalnya, Inggris dan Amerika, penulisan, penerbitan dan penjualan buku-buku ini telah menjadi suatu industri yang fenomenal. Dalam industri ini, muncul banyak penerbit yang mengkhususkan diri pada penerbitan novel dengan subgenre tersebut dan dalam penjualannya, mereka mampu bersaing dengan novel novel fiksi lain yang ditujukan untuk pembaca umum. Hal ini terkait erat dengan makin banyaknya penulis wanita yang menerjunkan dirinya dalam menghasilkan karya karya dalam subgenre ini, sehingga judul judul baru dari penulis dan penerbit berbeda berlomba lomba menarik minat pembaca wanita. Chicklit muncul pada pertengahan 1990-an di Inggris lewat kehadiran 
Bridget Jone's Diary karya Helen Fielding, The Girl's Guide to Hunting and Fishing karya Melissa Banks, serta The Nanny Diaries karya Emma Mclaughin dan Nicola Krause. Novel karya Helen Fielding ini terbit pada tahun 1996. tema yang diangkat dalam novel ini adalah Big is beautiful. Hadirnya buku ini memberi peluang kepada perempuan untuk menulis sehingga muncullah karya-karya sejenis yang kemudian diberi label chicklit.

Fenomena chicklit di Indonesia baru mulai terlihat sekitar tahun 2004 dan 2005. Dalam dunia perbukuan muncul novel-novel yang diberi label chicklit dengan tambahan tulisan being single and happy. Selain label chicklit kemudian muncul pula label teenlit yang lebih ditujukan bagi pembaca remaja. Ini adalah sebuah istilah baru yang diciptakan oleh perindustrian buku di Indonesia. Seri pertamanya berjudul Buku Harian Bridget Jones diterbitkan oleh Gramedia Pustaka Utama. Hingga saat ini telah memasuki cetakan ke-3 dan terjual sebanyak 15 ribu eksemplar dan terbit pertama kali pada tahun 2003. Sampai saat ini kurang lebih sudah 24 judul yang terbit. Novel ini dapat dikatakan sebagai pelopor untuk genre ini. Novel setebal 271 halaman ini memang merupakan sebuah fenomena. Buku tersebut menurut ABCNEWS sempat meraup lebih dari 71 juta dollar atas penjualannya.

Chick lit buatan penulis Indonesia yang menjadi sangat terkenal berjudul Cintapucinno karya Nisha Rahmanti, yang terbit pada bulan Juni 2004 dan kini sudah memasuki cetakan ke-8. Novel ini berhasil mencapai predikat best seller. Berikutnya 
muncul pula karya-karya Albertine Endah dengan Cewe Matre yang diberi label "lajang kota”. Penulis ini dengan sangat sadar berniat untuk memberi label karyanya sebagai seri "lajang kota". Keberadaan novel-novel tersebut memunculkan karya-karya lainnya bahkan kemudian diikuti dengan penulisan teen lit yang diperuntukkan bagi remaja.

\section{Formula dan Kemasan Chick Lit}

Chick lit ditujukan pada wanita muda, lajang dan mandiri seperti slogan yang dicetak pada sampul depan luar chick lit yaitu "being single and happy" dan pada sampul depan dalam yakni target pembacanya dipaparkan sebagai "para wanita muda yang cerdas, mandiri, berani, jujur pada diri sendiri, para wanita kosmopolitan yang umumnya masih lajang, punya karier dan bergelut dengan berbagai masalah kehidupan modern. Karya-karya ini dengan jelas sekali menekanan pada kelajangan dan menikmatinya. Hal ini merupakan salah satu ciri pembeda chick lit dengan karya-karya lainnya. Dari segi alur ceritanya lebih menekankan pada pencarian jati diri si tokoh utama wanita daripada menemukan cinta sejati. Meskipun ada masalah percintaan, hal ini tidak menjadikannya sebagai satu satunya plot utama karena ada subplot seperti persahabatan, masalah di kantor dengan teman atau si bos atau masalah dengan orang tua. Adegan seks yang digambarkan tidak ditampilkan secara eksplisit. Akhir kisah si tokoh wanita tidak harus berakhir dalam perkawinan, walaupun akhirnya menemukan seorang pria yang benar benar dicintainya. Cerita bisa berakhir dalam suatu perkawinan, hidup bersama atau berpacaran saja. Cerita dalam chick 
lit dituturkan dari sudut pandang si tokoh wanita lajang. Si tokoh wanita lajang bukanlah tokoh panutan dan digambarkan sebagai anti role model protagonist karena tidak cantik, bukan gadis suci, menyukai kemewahan dan uang serta tidak merasa perlu untuk menyangkalnya, memiliki pekerjaan, tetapi tidak terlalu sukses, mendambakan kesuksesan, dan memiliki satu "kelemahan fatal" yang menyebabkan masalah. Kelemahan fatal ini bisa berupa obesitas seperti pada karakter Jemima dalam Jemima Jones, gila belanja pada Becky Bloomwood dalam Shopaholic, ukuran dada yang terlalu kecil dan kelemahan kelemahan fatal lainnya yang sangat manusiawi yang biasanya menyakiti dirinya sendiri. Akan tetapi, dibalik segi negatif ini, si tokoh wanita adalah orang yang sangat hangat yang menghargai persahabatan, kesetiaan, dan kejujuran. Kesuksesan si tokoh diukur dari keberhasilannya mengontrol, tetapi tidak menghilangkan kelemahannya, sehingga terjadi banyak adeganadegan lucu sebagai akibat kelemahan si tokoh. Dengan permasalahan seperti ini, gaya bercerita penulis juga penuh nuansa humor sehingga penggambaran si tokoh menjadi komikal. Hal ini menjadikan pembaca tertawa, tidak menertawakan, tetapi tertawa bersama si tokoh yang mampu menertawakan dirinya sendiri. Chick lit dapat dikatakan lebih mewakili berbagai permasalahan wanita lajang perkotaan masa kini yang telah meninggalkan nilai nilai puritan.

Mengingat unsur unsur humor yang menjadi trademark chick lit, desain sampul depannya pun didesain sesuai dengan gaya chick lit. Gambar gambar komikal berjenis kartun selalu menghiasi baik sampul depan maupun belakang diatas warna sampul yang 
meriah seperti warna merah, biru, hijau terang, atau warna warna pastel lembut yang sangat feminin. Jika si tokoh digambarkan di sampul, pembaca akan mendapati gambar kartun si tokoh wanita yang memiliki mimik riang dalam balutan busana kantor atau busana malam yang trendi, sopan dan tertutup. Dengan sampul seperti ini, pembaca bisa dengan cepat mengenali sebuah chick lit. Disamping itu, penampilan novel chicklit ditandai dengan jumlah halaman yang berkisar antara 400 hingga 500 halaman, sehingga cukup tebal untuk menarik perhatian.

Chicklit memiliki "formula baku”. Terjadi pertemuan antara si wanita dan tokoh pria bisa ada ketertarikan fisik secara langsung, kemudian terjadi konflik diantara mereka karena perbedaan prinsip hidup. Akhirnya mereka mampu menyelesaikan masalah dan memutuskan untuk hidup bersama. Formula tersebut juga mengharuskan si tokoh wanita mempunyai seorang atau beberapa sahabat setia yang selalu mendukungnya. Pembaca chick lit juga sudah mengenal formula yang ada dan berharap menemukan formula tersebut pada chick lit yang mereka baca. Kesuksesan sebuah chick lit sangat bergantung pada kesetiaan alur cerita pada formula tersebut. Penggemarnya disuguhi beberapa varian dari formula yang ada yaitu pada jenis kelemahan fatal sang tokoh yang berbeda antara satu novel dengan novel lainnya.

Pengulangan membaca suatu formula tidak membuat pembaca jenuh, sebaliknya ia membuat pembaca semakin ketagihan dan selalu merasakan suatu kesenangan ketika menemukan judul baru. Kemasan dan karakteristik novel roman dan chick lit berbeda 
karena menyesuaikan dengan usia penggemarnya yang berbeda, tetapi kesamaan yang dimilikinya menjadikan kedua genre ini sebagai bacaan khas kaum wanita.

Untuk chicklit Indonesia ditandai dengan judul-judulnya yang sebagian menggunakan bahasa asing dan sebagian bahasa "gaul", seperti terlihat pada judul Cintapucinno, Cewe Matre, Jilbab Spears, Aku vs Sepatu Hak Tinggi, Because I love You, dan Beautiful Stranger. Novel chicklit biasanya berkisah tentang kehidupan perempuan kesepian dengan setting urban, dengan gaya hidup yang terkini, terbaru, keren, dan sedikit nakal. Mereka biasanya tengah mencari identitas dan tengah mencari pendamping yang sempurna. Hal ini misalnya dapat dilihat dalam karya Jane Green yang berjudul Straight Talking yang diterjemahkan ke dalam bahasa Indonesia dengan judul Apa Adanya Saja. Novel ini berkisah tentang seorang perempuan bernama Tasha (Anastasia), seorang perempuan lajang profesional berusia tiga puluh tahun yang bekerja sebagai produser televisi.

Pengisahan dalam novel ini menggunakan sudut pandang aku-an yang sering secara langsung menyapa pembacanya sehingga seolah-olah pembaca diajak berkelana ke alamnya. Pembaca seperti diajak membaca buku hariannya.

Bisa jadi aku keliru, tapi aku berasumsi kalian juga termasuk dalam kelompok persaudaraan perempuan, sebab kalau tidak, tidak mungkin kita mengobrol seperti sekarang. Tapi, kita toh masih dalam 
tahap saling mengenal. Bertahanlah, mungkin ada pelajaran berharga yang bisa kalian petik dari ceritaku ini (Green/2005/20).

Seperti sudah disebutkan bahwa novel jenis ini mengisahkan seksualitas secara advonturir. Hal tersebut juga terlihat dalam novel ini. Tasha sebagai seorang perempuan lajang dan kelompoknya sering dijuluki sebagai ladette-yang artinya perempuan liar yang suka minum. Novel ini mengisahkan sepak terjang Tasha yang pada saat itu sedang mencari seorang laki-laki sebagai calon suami yang potensial. Secara fisik Tasha digambarkan sebagai seorang perempuan lajang yang glamour dan menggairahkan.

Kau tahu, di situlah letak masalahnya. Ketika pertama kali bertemu denganku, kebanyakan lelaki mengira aku tipe wanita berbahaya, glamour, dan menggairahkan (Green/2005/13).

Sebagai seorang perempuan dengan tipe fisik sedemikian, Tasha seringkali harus berhubungan dengan laki-laki yang hanya ingin mencoba untuk 'menidurinya' saja. Lakilaki memandang Tasha sebagai perempuan yang tidak memerlukan komitmen dalam hubungannya dengan laki-laki. Namun, apakah benar demikian? Apakah Tasha memang seorang perempuan yang hanya mementingkan advonturir seks dengan laki-laki? Apakah 
hal ini merupakan formula chick-lit yang kemudian menyebabkan karya-karya yang digolongkan jenis ini sebagai karya yang termasuk jenis postfeminis?

Sejak awal novel ini sudah memberikan tanda bahwa tokoh Tasha bukanlah tipe perempuan seperti yang terbayangkan dari penampilannya. Memang dia digambarkan sebagai perempuan profesional yang hidup di dunia modern yang penuh serba kemungkinan. Dia digambarkan sebagai perempuan lajang pekerja yang secara fisik memungkinkan masyarakat untuk memandangnya demikian. Namun, dari awal novel ini sudah disebutkan bahwa Tasha menyebutkan dirinya sebagai wanita klasik yang keras di luar tetapi lembut dan halus di dalamnya. Karena penampilan luarnya tersebut disebutkan oleh Tasha bahwa tidak ada selama ini laki-laki yang pernah mencoba untuk melamarnya.

Bukan berarti aku tidak pernah punya pacar lho, meski harus kuakui, tidak seorang pun di antara mereka pernah berniat melamarku. Padahal aku sudah nyaris menganggap mereka calon suami potensial. (Green/2005/8).

Perempuan ini memang ingin mencari suami. Dia tidak berbeda dengan perempuanperempuan lain, hanya karena kehidupan melajangnya di dunia yang modern menyebabkan keinginannya tersebut diwarnai oleh beberapa pengertian yang dapat membedakannya dengan perempuan-perempuan lain. 
Apa yang disampaikan oleh Tasha sebenarnya menandai bahwa dia berada dalam dunia feminis dan sekaligus maskulin. Tasha menyadari sepenuhnya bahwa laki-laki itu berbahaya bagi kehidupannya sampai ada suatu saat tokoh ini mengandaikan bahwa dunia akan menjadi aman kalau hanya ada perempuan saja.

Tapi tidak terlalu kelihatan palsu, hanya sekadar memberi sentuhan warna cokelat sehat. Aku siap menghadapi dunia, asalkan hanya ada wanita di dalamnya (Green/2005/43).

Namun, di sisi yang lain digambarkan bahwa Tasha saat berhubungan dengan lakilaki bertingkah laku sebagai seorang perempuan pengurus rumah tangga. Ini berarti Tasha berada dalam dunia maskulin.

Aku memasak untuk Simon, membersihkan rumahnya dan mengurus segala keperluannya. Aku membawakan baju-baju kotornya ke binatu, dan jelas sudah, kalian para pembaca yang cerdas pasti sudah bisa menebak, bahwa itu awal dari akhir kisah cintaku (Green/2005/73). 
Hal seperti inilah yang menyebabkan karya-karya yang digolongkan sebagai chick lit disebut berada dalam posisi di perbatasan-on the edge. Persoalan lain yang mendukung pernyataan ini adalah munculnya konflik utama novel ini yang mengarah pada persoalan gairah sebagai penanda hubungan antara laki-laki dan perempuan. Tasha menolak kekasihnya yang juga sahabatnya karena dia merasakan gairah terhadap laki-laki itu. Dia mencoba untuk mencari gairah pada laki-laki lain, tetapi pada saat dia ingin membuktikan gairahnya tersebut. Tasha telah gagal dan menyadari bahwa hubungannya dengan Adam, kekasih dan juga sahabatnya merupakan hubungan yang sebenarnya bagi dirinya sendiri. Ini membuktikan sekali lagi bahwa karya ini memang berada dalam sebuah batas, batas antara masa-masa tradisional dan modern, batas antara pemahaman tentang cinta itu sendiri yang diartikan sebagai gairah, kekaguman, dan rasa hormat. Gairah mewakili alam kosmopolitan dan modern, sementara kekaguman dan rasa hormat mewakili alam tradisional dan klasik yang masih dimiliki oleh Tasha.

Dari paparan di atas dapat dibuat simpulan sementara bahwa chick lit yang ditulis oleh salah seorang penulis asing memunculkan formula khas sebagai karya sastra yang bersifat populer. Cerita-ceritanya diangkat dari seputar dinamika hidup orang-orang perkotaan, khususnya perempuanyang identik dengan cara berpikir modern, tidak ketinggalan dalam hal mode: pakaian, rambut, jenis parfum yang disemprotkan, dan ukuran kelas sosial lainnya yang menjurus pada kosmopolitanisme. Dari aspek estetika kesastraan, fenomena chick lit dan teen lit ini lebih mudah diterima masyarakat karena gaya 
bertuturnya yang ringan, mengangkat cerita hal-hal yang sepele, sangat menghibur, dan biasanya ditulis dengan teknik penceritaan semirip buku harian. Jadi, secara emosional jelas membangkitkan keterlibatan pembaca.

Karya yang digolongkan ke dalam kelompok ini memang sering disebut sebagai serangan balasan terhadap gerakan feminisme sebagaimana disampaikan oleh Stacy Gillis. Mengapa? Sebagaimana terlihat dalam karya Jane Green tokoh utama novel ini Tahsa digambarkan sebagai seorang perempuan lajang yang memiliki karier, berpenampilan modern dan bergaya hidup kosmopolitan yang seharusnya memiliki pola pikir postfeminis ternyata memiliki pola pikir klasik yang memimpikan dan menjadikan pernikahan sebagai tujuan utamanya. Dalam hal ini tampak serangan yang cukup telak terhadap feminisme sebab paparan tentang tokoh perempuan yang ada di dalam novel tersebut sangat mengangungkan komitmen sebuah hubungan antara laki-laki dan perempuan. Selain itu, hubungannya dengan Adam, laki-laki yang kemudian menjalin komitmen dengan dirinya dimulai dengan pandangan dari laki-laki itu bahwa Tasha merupakan perempuan rapuh yang perlu dilindungi

Bagaimana dengan chick lit lokal? Apakah memiliki formula yang serupa dengan karya-karya terjemahan tersebut. Kemasan chick lit lokal tidak jauh berbeda dengan karya terjemahan. Warna-warna mencolok juga mendominasi. Pengarang chick lit lokal adalah perempuan-perempuan, ceritanya juga ditujukan untuk perempuan. Hanya ada perbedaan mencolok dengan karya terjemahan. Buku-buku itu tidak semuanya ditulis dengan teknik 
buku harian sebagaimana terlihat dalam chick lit terjemahan. Gaya berceritanya lucu, dan ada nada terus terang yang dicoba dipaksakan. Gaya bercerita tidak berbeda dengan novelnovel populer lainnya. Beberapa mungkin berbeda, tetapi pada umumnya kemunculan latar atau setting luar negeri, entah itu Amerika, Prancis, atau Inggris menjadi sebuah mode. Selain itu, gaya berpakaian dan penyebutan merek-merek ternama untuk menandai kehidupan glamour di perkotaan muncul. Hal itu, misalnya, muncul dalam sebuah novel yang berjudul Cinta Kuya karangan Charmanita S. Adji.

Kaver novel ini ditandai oleh sebuah gambar seorang perempuan dengan warna rambut pirang dan dandanan menor memakai kaos oblong di atasnya muncul tulisan Love Sucks. Warna pastel kaver novel ini serta tulisan chick lit ciri pop Indonesia menandai sampul depan novel ini. Cinta Kuya mengisahkan kehidupan seorang gadis bernama Naya atau Kuya, nama panggilan kesayangan bagi gadis ini. Naya adalah seorang gadis yang disebutkan dipaksa cepat matang karena pada usianya yang ke-16 harus hidup sendirian di Amerika.

Konflik utama dalam novel ini berbeda dengan karya terjemahan. Seperti umumnya novel-novel populer lainnya kisah dalam novel ini adalah pencarian seorang kekasih dengan rasa cinta sejati. Cinta sejati inilah yang menjadi tumpuan impian dan cita-cita sang Kuya, perempuan muda profesional yang pernah hidup di Amerika. Tampaknya setting Amerika yang dimunculkan oleh pengarangnya tidak memiliki pengaruh apa pun terhadap idiologi teks. Tidak muncul pernyataan apa pun yang mengarah bahwa Naya memiliki 
pandangan hidup sebagai seorang feminis atau seorang perempuan klasik. Dia berhubungan dengan pacar-pacarnya disebabkan oleh cinta platonis, tidak ada nada keterusterangan seperti yang tergambarkan dalam karya Green. Perempuan ini ditinggal oleh pacar pertamanya, Raja karena sang kekasih dijodohkan oleh orang tuanya. Persoalan ini hanya diungkapkan pada posisi permukaan saja, hanya sebagai penyebab perginya sang kekasih dari sampingnya.

"Kamu harus tegas dong, Ja! Kamu tu cowok! Kamu harus punya sikap. Bilang dong terus terang sama ibu kamu kalo kamu sekarang lagi berhubungan sama aku dan kamu happy dengan itu. Kamu nggak mau dijodoh-jodohin sama orang lain karena kamu mencintai aku!"’. (Adji/2005/20).

Naya mengalami kehidupan serba bebas. Dia memiliki kontrakan sendiri padahal orang tuanya tinggal satu kota. Dari gambaran ini pengarang tampaknya ingin menggambarkan kehidupan bebas seorang perempuan kosmopolitan yang sukses dalam kariernya. Naya memang seorang profesional. Dia memiliki karir yang bagus sebagai seorang manajer sebuah band terkenal. Setting yang sedemikian menggambarkan kehidupan modern, tetapi apakah memang seorang Naya adalah seorang perempuan moden? Gaya hidup Naya memang memberikan gambaran kehidupan seorang perempuan 
modern, tetapi sebenarnya dia adalah perempuan Indonesia biasa yang mendambakan kehidupan dan pola pikir secara tradisional.

Yang menarik dari novel ini, pada halaman sampul belakang muncul komentar yang menyatakan bahwa kisah diri sang pengarang mirip kisah diri tokoh utama novel tersebut.

My story...

Lahir di Jakarta 8 Maret 1977 sebagai anak terkecil dari 3 bersaudara yang cewek semua udah nyebur di dunia entertaiment dari taun 1997. dimulai dari kerja di PH terus jadi Road Manager beberapa band gede, n' sekarang jadi manajer kreatif alias mandornya para tukang bikin konsep acara di sebuah eo. Beneran pernah sekolah di Seattle ngambil multimedia setelah masa kecilnya diabisin di Bogor. Punya hobi baca, nulis, nyanyi, kerja \& makan, makanya terciptalah sosok Naya yang langsing dan cantik, sesuai dengan mimpinya selama ini. Punya banyak pengalaman nyakitin n' disakitin cowok (maca'ciiihhh..?!) jadi agak agak dendam gitu sama namanya cinta love memang sucks, (Adji/2005/halaman belakang).

Di belakang sampul ini dimunculkan kisah demikian, tetapi dari segi gaya novel ini tidak dapat dinyatakan sebagai novel yang memakai gaya buku harian. Sebagai sebuah karya sastra novel ini seratus persen berada dalam dunia sendiri. Sudut pandang aku-an memang digunakan, tetapi keterlibatan pembaca tidak terlihat. 
Uhhh..Basi!!!! kalau sudah begitu, aku Cuma bisa mengumpat dalam hati sambil tetap memasang senyum, mengucapkan terima kasih, lalu pergi dengan penuh percaya diri, hanya untuk menunjukkan bahwa tanpa bekerja di majalah itu pun, aku akan tetap hidup bahagia. Srew you! (Adji/200/2).

Apa pun yang terjadi, novel karya Charmanita ini sudah muncul di dunia penerbitan Indonesia dan meramaikan kehadiran sebuah genre yang saat ini sedang digembor-gemborkan sebagai wabah yang sedang menjangkiti masyarakat pembaca sastra Indonesia. Formulanya memang berbeda dengan karya terjemahan yang ada. Persoalan yang dimunculkan juga berbeda. Cara pandang yang ditampilkannya pun berbeda. Selain itu, nada keterusterangan tidak muncul padahal ini merupakan ciri khas sebuah chick lit. Apa pun penilaian yang diberikan sebagaimana dikemukakan oleh Soni Farid Maulana bahwa genre ini apa pun jadinya karya-karya tersebut harus diakui sebagai bagian dari warga sastra Indonesia sebab batas antara sastra populer dan sastra serius saat ini sudah mulai diragukan keberadaannya.

\section{Chik-lit di Indonesia}

Munculnya chick lit di Indonesia dimulai dengan adanya karya-karya terjemahanyang di negeri asalnya - tidak dilabeli sebagai chick lit. Sukses yang diraih oleh karyakarya terjemahan tersebut menginspirasi penulis-penulis Indonesia untuk juga menulis dengan gaya seperti ini. Diawali oleh seorang Nisha Rahmanti, seorang arsitek dari 
Bandung, dengan bukunya yang berjudul Cintapucinno. Kemudian ada Albertine Endah dengan novelnya Cewe Matre, kemudian diikuti oleh penulis penulis lain.

Perkembangan selanjutnya ada sejenis Chick lit yang ditujukan untuk para gadis remaja usia belasan tahun yang dilabeli sebagai teen lit dari teenager, terlepas dari setuju atau tidak setuju dengan pengokatakan pembaca, jenis novel-novel tersebut harus diakui keberadaanya di dalam lingkungan kesusastraan Indonesia. Nisha Rahmawati penulis yang selama ini dilekati dengan label penulis chick-lit mengungkapkan bahwa penulisan novel tersebut diinsipirasi oleh keberadaan chick lit terjemahan yang sedang booming di pasaran.

Tentang novelnya, Icha menyatakan, ide awalnya berangkat dari keinginannya membuat chick-lit Indonesia asli di tengah maraknya chick-lit luar. "Jadi, saya punya tagline, sudah waktunya perempuan Indonesia memiliki ceritanya sendiri." Indopos/2005/4/16).

Sampai saat ini novel tersebut sudah memasuki cetakan ke-12 dan terjual lebih dari 25.000 eksemplar dan meraih predikat bestseller. Novel dengan gaya tersebut dianggap oleh masyarakat pembacanya sebagai karya yang menceritakan peristiwa yang sesungguhnya, seperti yang terjadi pada novel Cintapucinno. Hal tersebut dapat terjadi karena gaya yang dipakai memperlihatkan kedekatan dengan pembaca, bahkan dalam karya 
terjemahan seperti dalam Straight Talking, pembaca diajak bercakap-cakap. Novel-novel tersebut memang dibentuk dengan sudut pandang aku-an yang menjadikan novel-novel tersebut serasa dekat dengan pembaca. Pembaca memang dengan sengaja disapa oleh narator.

Saat ini cukup banyak karya yang dapat digolongkan sebagai chick lit dan teen lit buatan Indonesia, antara lain Jilbab Spears, Aku vs Sepatu Hak Tinggi,Bacause I Love You, Beatiful Stranger, Buku Harian Terlipat Cadar, God is A Girl,Di Selubung Malam, dan masih banyak lagi. Sementara itu, penulisnya selain sudah disebutkan Nisha Rahmawati dan Albertine Endah, juga ada Asma Nadia dan Novia Syahidah yang menulis Di Selubung Malam. Ada pula Novita Estiti yang menolak bukunya Subject Re sebagai karya yang dapat digolongkan sebagai chick lit.

Keberanian penulis-penulis chick lit di Indonesia selain dipicu oleh laris manisnya karya terjemahan yang dilabeli sebagai chick lit juga disebabkan oleh kondisi dunia kesusastraan Indonesia pada era 2000-an yang seakan-akan dikuasai oleh kaum perempuan dengan pelopornya Ayu Utami dengan novelnya Saman. Dalam bukunya Cewe Matre, Albertine Endah mengakui bahwa Ayu Utami adalah salah satu inspiratornya./Inspirasi dan penyemangat, Ayu Utami, Rudy Gunawan, dan Fira Basuki (Endah, 2005). Pengakuan tersebut memang relevan dengan kondisi pada era tersebut.

Era 2000-an memang dapat dikatakan sebagai zamannya penulis perempuan bagi kesusastraan Indonesia, bahkan pada tahun 2004 pemenang sayembara menulis roman 
DKJ diduduki oleh perempuan semua. Tiga hadiah yang disediakan semuanya diraih oleh para perempuan. Belum lagi penulis-penulis perempuan lainnya yang tidak mengikuti sayembara tersebut, tetapi eksis dalam dunia sastra Indonesia, seperti Djenar Maesa Ayu dengan beberapa kumpulan cerpennya, Nova Riyanti Yusuf, dan Fira Basuki.

Penulisa perempuan tersebut sering mendapat julukan sebagai bagian "sastra wangi". Sebutan tersebut muncul sebab rata-rata penulisnya menjadi populer. Selain karyanya, pengarangnya sendiri menjadi populer seperti artis, bahkan ada beberapa di antaranya memang seorang artis, sebut saja Rieke Diah Pitaloka, Si Oneng dalam Bajaj Bajuri. Hal ini merupakan pertanda bahwa sastra yang mereka usung memang dekat dengan dunia selebritis. Bahkan untuk boomingchick lit dan teen lit di Indonesia dipicu juga oleh dunia film, yaitu film Ada Apa dengan Cinta? Yang kemudian dijadikan sinetron. Keberadaan film tersebut agaknya mulai mendekatkan remaja pada bacaan sastra disebabkan karakter tokoh Rangga yang diberi label oleh sutradaranya sebagai seorang remaja yang cinta sastra.

Kedekatan dengan dunia selebritis dan pada akhirnya dunia perfilman tersebut memang merupakan salah satu ciri chick lit. Bahkan sebagai pelopornya Bridget Jones Diary juga meraih sukses di dunia perfilman. Film yang diangkat dari kisah novel ini sempat meraih box office. Ini merupakan sebuah realitas menarik bagi dunia kesusastraan yang selama ini rasanya sering disebut sebagai dunia di menara gading. 
Kedekatan dengan dunia selebritis ini nantinya akan menjadi salah satu penyebab laris manisnya novel-novel tersebut.

\section{Tanggapan Pembaca terhadap Chick Lit}

\section{KaryaChick Lit}

Sebelum membicarakan bagaimana tanggapan pembaca terhadap chick lit, seorang penelaah tanggapan harus terlebih dahulu mengetahui apa yang menjadi objek tanggapannya yakni karyayang dikelompokkan sebagai chick lit. Tidak hanya kemasan dan gaya penulisan, tetapi unsur apa yang dibicarakan dalam chic klit memang agak sedikit berbeda dengan novel-novel lainnya. Chick lit berhasil secara terbuka merepresentasikan masalah perempuan, khususnya masalah seputar dunia lajang. Para perempuan tokohnya digambarkan memiliki masalah manusiawi, dalam ukuran berat badan, penampilan, gaya hidup, obsesi terhadap mode, hingga patokan laki-laki ideal dan lelaki idaman. Sebagaimana diungkapkan oleh F. Dewi Ria Utari dalam salah satu artikelnya di majalah Tempo bahwa dalam chick lit "perempuan menemukan keberanian menyatakan kegelisahan hidupnya tanpa harus takut pada stempel—entah korban mode, hedonis, alih-alih takluk pada patriaki. Yang penting bahagia dalam hidup" (Tempo,2005/2/6).

Hal yang demikian tidak hanya terlihat pada chick-lit terjemahan, tetapi juga sudah mulai menggejala dalam karya-karya yang ditulis oleh orang Indonesia. Dalam novel Cewe Matre karya Albertine Endah dengan gamblang dijelaskan bahwa tidak 
mudah hidup di Jakarta yang kemudian memunculkan gadis-gadis yang kemudian disebut sebagai"cewe matre". Persoalan "cewe matre" ini memang menjadi persoalan pokok dalam karya ini. Dikisahkan ada seorang perempuan bernama Lola, dia cantik, pintar, bekerja di sebuah radio sebagai humas, tetapi tidak merasa berbahagia. Gadis ini iri dengan penampilan perempuan-perempuan lain yang dapat tampil gaya dengan merek-merek yang branded.

Seperti halnya karya chick lit yang lain kemunculan sahabat atau teman menjadi cukup penting. Lola bersahabat dengan Palupi, Silvia, dan Renata. Keempat gadis ini hidup di lingkungan metropolis dengan gaji pas-pasan. Bermula dari cetusan ide yang disampaikan oleh Silvia, bahwa Lola cantik dan dia dapat memanfaatkan kecantikannya untuk menggaet dan menguras kantong laki-laki. Tentu saja kehidupan baru yang dijalani oleh Lola sangat bertentangan dengan "moralitas" masyarakat. Muncullah konflik, Lola yang masih memiliki hati nurani pun kembali ke asalnya, kemudian menyadari bahwa uang tidak hanya dapat diperolehnya dari laki-laki.

Yang menarik dari novel yang oleh pengarangnya diberi label sebagai seri "Lajang Kota" ini adalah kepandaian penulisnya untuk tidak terjebak dalam akhir kisah yang klise (kalau dapat dikatakan demikian). Dikisahkan di dalam novel ini bahwa sang tokoh sebenarnya sudah bertemu dengan seorang pemuda yang berasal dari keluarga kaya, kalau dapat dikatakan sang gadis sudah bertemu dengan pangeran impian, tetapi penulis tidak mengakhirinya dengan ending "demikianlah sang putrid hidup berbahagia 
dengan sang pangeran untuk selamanya”. Penulis mengakhiri kisahnya secara terbuka. Lola tidak harus bersama Clift, tetapi ingin mencoba menjadi dirinya sendiri.

"Saya ingin mengembalikan diri saya pada sesuatu yang saya yakini

benar. Kemudian waktu akan menentukan, apakah kita akan kembali

berjalan, atau tidak..."

Clift terdiam. Matanya menelusuri wajah saya.

“Clift, saya ingin kerja. Kayak kamu dan Glen.” (Endah/2005/454)

Problema yang dihadapi oleh tokoh utamanya, Lola, diakhiri dengan pilihan terbuka. Aapakah Lola akan terus menjadi lajang atau dia akan hidup berbahagia dengan Clift. Pembaca diminta untuk memikirkannya sendiri.

Berbeda dengan Cewe Matre akhir kisah Cintapucinno adalah akhir yang tertutup. Sang tokoh utama akhirnya dapat hidup berdampingan dengan laki-laki yang selama 10 tahun menjadi obsesinya. Novel ini memang tentang sebuah obsesi. Obsesi seorang gadis bernama Rahmi. Gadis ini mulai dari SMU sampai kuliah terobsesi menjadi pacar seorang pemuda bernama Nimo. Obsesinya membuat dia tidak dapat memisahkan antara kenyataan dan impian. Bahkan pada saat Rahmi sudah menemukan seorang kekasih, Raka menurut semua orang dalam novel tersebut diberi label sebagai tokoh yang baik.

Ada perbedaan lainnya yang menarik dari dua novel ini, yaitu soal narrator yang digunakan. Pada novel Cewe Matre digunakan kata ganti "saya" untuk naratornya, 
sementara pada novel Cintapucinno digunakan kata ganti "aku”. Keduanya memakai sudut pandang yang sama yaitu sudut pandang "akuan". Hanya saja di dalam Cewe Matre terasa ada sedikit kekauan karena penggunaan kata "saya" tersebut. Keakraban yang diciptakan agak melonggar dengan sebutan tersebut. Hal itu, dapat dikatakan bahwa pengarangnya memang menginginkan efek yang berbeda dengan sebutan tersebut. Pengarangnya tampak memunculkan jarak antara narator dengan pembacanya. Hal tersebut semakin tampak jelas saat sang narrator menyapa pembaca dengan sebutan "Anda"./Aha. Seperti yang sudah diduga, respons Anda muncul dengan skenario terbaca/ (Endah/2005/7).

Kutipan tersebut membuktikan bahwa sang tokoh utama sebagai sebuah pribadi yang diciptakan berbentuk "cewek matre" berada di dunia berbeda dengan pembaca yang dianggap oleh pengarang sebagai dunia yang masih memiliki "moralitas" tinggi. Dengan kata lain, dunia sang "cewek matre" berbeda dengan dunia Anda yang dikatakan orang sebagai orang baik-baik. Oleh karena itu, wajarlah apabila harus diciptakan petedaan di antara keduanya.

Selain dua novel tersebut, ada disebutkan pula novel-novel lainnya di antaranya $D i$ Selubung Malam karya Novia Syahidah. Novel ini agak berbeda dengan kelompoknya. Oleh karena itu, karya ini tetap dipertahankan sebagai karya dalam kelompok chick lit tentunya akan memberikan warna bahwa sebuah karya chick lit dari segi kualitas dapat dipertanggungjawabkan. Novel ini, sebagaimana disampaikan oleh Satmoko Budi Santoso (2005: 3) dinyatakan sebagai sebuah novel mempertaruhkan wacana antropologis dan 
sosiologis budaya Lombok telah memberikan masukan brilian terhadap pengembangan rasionalisasi cultural studies yang begitu berharga dalam menyosialisasikan kekayaan warna budaya lokal yang ada di Indonesia. Memang diakui bahwa novel jenis ini terutamanya mengisahkan kehidupan para perempuan metropolis, tetapi apabila karyakarya yang digolongkan ke dalam jenis ini berani mengeksplorasi substansi pergeseran budaya masyarakatnya atau tentang shock culture-nya, secara kualiyas karya-karya tersebut dapat diperhitungkan kehadirannya.

Sebuah karya lagi yang disampaikan oleh Satmoko (2005: 3) adalah sebuah karya berjudul Belajar Nakal (Catatan Berantakan dari Kota Setengah Gila) yang ditulis oleh Adhe Ma'ruf. Gaya penulisannya slengekan, tetapi menampilkan secara komprehensif gambaran pergeseran budaya di kota Yogyakarta. Karya-karya tersebut ternyata memiliki perspektif beda untuk penulisan sebuah karya yang dapat digolongkan sebagai chick it atau teen lit.

Sebagaimana karya-karya tersebut novel Cewe Matre karya Albertine Endah tampaknya punya keinginan untuk menyampaikan pergeseran budaya tersebut. Budaya yang mengagungkan penampilan dengan merek-merek branded menampakkan gejala umum dalam masyarakat perkotaan dalam lingkungan tertentu. Gaya hidup hedonis sebagaimana terungkap dalam novel ini yang menjadi persoalan utama. Tokoh perempuan dalam novel ini digambarkan hidup dalam dunia serba gemerlap yang juga disebabkan oleh tuntutan profesinya harus tampil "gaya". Sang tokoh dikisahkan bekerja sebagai humas di 
sebuah radio yang mengunggulkan "gaya". Selain itu, lingkungan sekitarnya juga berbentuk masyarakat hedonis.

Iya, iya. Tapi kenapa juga saya terjebak dalam hidup ketika mal menjadi bagian yang tak terpisahkan dari aktivitas sehari-hari. Bagaimana saya bisa menolak pergi jika seisi kantor saya semua pergi ke mal? Bagaimana saya tidak memimpikan mal, jika tiap hari di depan saya bersliweran orang-orang keren yang secara perlahan membangkitkan kesadaran saya bahwa hidup ini selain perlu makan, juga perlu penampilan. Bagaimana saya bisa keukeuh menjadi perempuan hemat bin pelit, jika semua orang yang saya temui saban hari memiliki segudang acara mulai dari nongkrong di kafe, boling, biliar, nonton bioskop, nonton konser musik, clubbing di Musro, makan di restoran kondang, dan belanja di mal! (Endah/2005/51).

Kondisi sedemikian menyebabkan tokoh utama dalam novel ini mengalami krisis identitas. Sang tokoh, Lola, dalam novel dikisahkan sedang mencoba untuk menemukan alternatif identitas dirinya sebagai perempuan lajang yang hidup di tengah masyarakat yang serba hedonis tersebut. 
Hal inilah yang diangkat sebagai konflik utama. Cukup menarik memang yang dilakukan oleh Albertine Endah dalam novelnya ini. Sang tokoh digambarkan harus melewati peristiwa yang memaksa untuk menyadari potensi dirinya sebagai seorang perempuan. Moralitas sang tokoh yang hadir sebagai "cewek matre" tidak ditampilkan sebagaimana yang terbayangkan. Kebetulan sang tokoh berasal dari sebuah keluarga yang hangat sehingga gonjang-ganjing dunia sekitar yang sempat menjerumuskannya tidak membuat dirinya tenggelam untuk selamanya. Ada satu hal yang ditekankan oleh pengarangnya yaitu perasaan "malu”. Kunci utama bahwa Lola masih memiliki rasa "malu" telah mengembalikan kesadaran pribadinya.

Tragedi di villa Clift. Penghinaan Philip. Komentar pria-pria di kantor saya. Kepergian Clift. Kehadiran Glen. Dan terlebih, kesadaran bahwa ternyata dalam tubuh saya masih ada sel bernama malu (Endah/2005/453).

Sebagaimana diungkapkan oleh Satmoko (2005:3) memang munculnya pergeseran budaya akan menambah kualitas karya-karya yang dikelompokkan sebagai chick-lit, dan karya Albertine Endah memang dapat dikelompokkan ke dalam karya yang mencoba untuk mengunggulkan kualitas dari sisi apa yang ingin diungkapkan oleh pengarangnya. 


\section{Tanggapan Pembaca}

Khalayak orang menilai bahwa keberhasilan chick lit adalah karena karya ini dapat merepresentasikan masalah perempuan saat ini secara terbuka, terutama permasalahan yang dihadapi di dunia lajang. Para tokoh perempuannya digambarkan memiliki masalah manusiawi, dari berat badan, misalnya dalam Bridget Jone's Diary karya Helen Fielding; penampilan dan gaya hidup, misalnya dalam Cewe Matre karya Albertine Endah; obsesi terhadap mode atau obsesi terhadap seorang laki-laki seperti dalam Cintapucinno karya Nisha Rahmawati hingga ke patokan laki-laki ideal, tanpa rasa malu untuk mengungkapkannya.

Sebagai sebuah karya seperti telah diulas dalam bagian sebelumnya tulisan ini bahwa chick lit akan berharga apabila mencoba untuk mempersoalkan pergeseran budaya yang berbentuk konkret misalnya pencarian identitas diri. Sehubungan dengan masalah identitas diri dapat dikatakan memang sejalan dengan apa yang dirasakan oleh pembacanya. Cukup banyak pembaca karya-karya yang masuk kelompok chick lit atau teen lit merasakan bahwa dari dalam karya-karya tersebut mendapatkan gambaran tentang dirinya sendiri atau istilah remajanya "gue banget".

Komentar semacam itu bahkan ditempel oleh salah seorang pengarang di sampul belakang halaman bukunya sebagai arena promosinya. Lucu, hidup dan cewek banget. (Rahmanti, 2005: sampul belakang). Komentar ini disampaikan oleh salah seorang penulis 
novel, Adhitya Mulya. Dengan bahasa yang berbeda Soni Farid Maulana juga mengungkapkan bahwa secara psikologis sejumlah karya yang dilabeli chick lit dan teen lit mampu menggambarkan dunianya, berikut impian-impiannya, dengan bahasa yang mereka pahami dan mereka kuasai (www.pikiran-rakyat.com). Tanggapan yang serupa juga datang pembaca awam yang memberikan komentarnya lewat media internet, misalnya seorang pembaca yang mengidentitaskan dirinya sebagai someone/critanya gue banget!/ beberapa karya memang dinilai demikian antara lain novel yang ditulis oleh Nisha Rahmanti yang berjudul Cintapucinno, Lovely Luna karya Upi Avianto yang ditanggapi oleh seorang pembacanya sebagai Abg banget.

Kedekatan dengan dunia pembacanya menunjukkan bahwa kualitas yang baik sebuah karya sastra apabila dilihat dari ukuran penilaian yang disampaikan oleh Jan Luxemburg dalam bukunya Tentang Sastra. Luxemburg (1989: 47-48) menyatakan bahwa salah satu aspek yang dapat menyebabkan sebuah karya sastra dinilai sebagai karya sastra yang bernilai adalah dimungkinkannya pembaca beridentifikasi dengan apa yang dikisahkan atau dikemukakan sebagai pendirian. Apabila kriteria tersebut yang digunakan dapat dinyatakan bahwa semua karya yang dikategorikan sebagai chick lit atau teen lit apabila dilihat dari posisi pembacanya dapat dinyatakan sebagai karya yang berhasil.

Kedekatan dengan dunia pembaca dalam karya-karya jenis ini juga didukung oleh pemakaian bahasanya yang "gaul banget" sebagaimana diungkapkan oleh salah seorang pembaca. Selain itu, juga disebabkan oleh bentuk penyajiannya yang oleh pelopornya 
ditulis berbentuk sebuah buku harian sehingga memberi peluang kedekatan dengan pembacanya. Sebuah buku harian adalah teman "curhat" bagi sang penulis. Niat pengarangnya pun sebagaimana terungkap dalam salah satu acara jumpa pengarang di Universitas Indonesia, bahwa chick lit dan teen lit adalah sarana untuk dapat "ngobrol" dengan sesama rekan sekerja. Identifikasi terhadap diri sendiri oleh pembacanya tampaknya juga disebabkan penulisnya adalah seorang perempuan masih muda, dan hidup di lingkungan yang hampir serupa dengan lingkungan yang juga dihadapi oleh pembacanya. Dengan demikian, dapat dinyatakan bahwa karya-karya chick lit dan teen lit dianggap sebagai karya yang berkualitas tinggi karena berhasil mengungkap atmosfir yang serupa dengan pembacanya.

Pembaca saat ini merasakan mendapat angin segar dengan adanya chick lit yang selama ini merasakan kekurangan bahan bacaan yang dapat memenuhi keinginan dirinya.

Maklum, selama ini minat baca remaja Indonesia dinilai rendah. Padahal, kita mungkin bukannya malas membaca buku. Cuma, bacaan yang ada nggak terlalu menggambarkan kehidupan kita sehari-hari. Ingin juga dong, membaca cerita-cerita yang mirip dengan pengalaman kita sendiri. (benny chandra.com) 
Dengan demikian dapat dinyatakan bahwa chick lit dapat mengisi kekosongan bacaan untuk remaja dan kelompok masyarakat lainnya. Tanggapan bahwa karya-karya chick lit dekat dengan pembacanya memunculkan tanggapan lain yang akan menggembirakan bagi semua orang yang berkecimpungan dalam dunia sastra Indonesia yaitu munculnya tanggapan yang berbentuk keinginan untuk menulis karya-karya serupa, misalnya terlihat dari pendapat eK@MaNiEZ berikut./Icha...keren Bangetz!!Sumpah gue mau diajarin bikin chick-litnya .../ Keinginan-keinginan untuk menulis buku setelah membaca chick lit cukup besar prosentasinya. Keadaan ini membuktikan bahwa memang chick lit ini dapat menjadi inspirasi bagi penulis-penulis pemula untuk berani menuangkan gagasannya dalam bentuk karya sastra sebagaimana terlihat dalam cuplikan pendapat seorang pembaca di internet berikut ini.

Ada beberapa tanggapan yang memberikan kesan-kesan negatif terhadap karyakarya sejenis chick lit. Hal itu sebagaimana dilansir oleh Soni Farid Maulana dalam artikelnya di internet, bahwa ada sebagian kalangan ilmuwan sastra menganggap karyakarya jenis ini sebagai karya sampah yang tidak akan ada nilai yang dapat dipetik dari dalamnya. Bagi Soni Farid Maulana bahwa harus disadari bagaimanapun karya-karya tersebut beda.

Apa yang mereka tulis, dan apa yang mereka alami dalam merenungi, menghayati, sekaligus pengalaman mereka dalam berbahasa dan mengolah kata; tentu sangat berbeda dengan apa yang 
ditulis oleh para sastrawan tersebut di atas. Karena itu, sungguh tidak layak bila kita tiba-tiba menjatuhkan vonis bahwa apa yang ditulis oleh para remaja itu, yang masuk ke dalam kategori sastra chick-lit dan teen-lit itu; disebut karya sampah (www.pikiran-rakyat.com).

Menarik juga tanggapan yang ditujukan untuk akhir sebuah cerita. Ada beberapa tanggapan yang menyatakan bahwa Cintapucinno di akhirnya kurang "sreng" karena akhirnya dia dapat meraih obsesinya sebagaimana diungkapkan Fei “cintapucino..hmmmm exactly kick my brain (naon siih) pokona mah baguus bgt walopun ending nya kurang hmmm kan enakan obsesi ttp jd obsesi seumur idup..he.."

Dari tanggapan semacam itu dapat dinyatakan bahwa memang karya-karya yang digolongkan sebagai chick lit ini diperhatikan dengan cukup serius oleh pembacanya Keseriusan tersebut juga membawa dampak bahwa sang pengarang harus mau "ngobrol bareng" dengan pembacanya di sebuah acara jumpa pengarang. Tinggal sekarang bagaimana memosisikan karya-karya jenis ini dalam dunia sastra Indonesia.

Beberapa orang pembaca menawarkan posisi sebagai “jembatan” bagi pembaca awam untuk masuk ke dunia sastra Indonesia. Hal tersebut dapat terjadi dengan tuntutan bahwa setelah membaca chick lit, sang pembaca awam, khusunya remaja yang baru mulai mengenal bahan bacaan semacam chick lit ini akan mulai masuk ke dunia sastra setelah 
merasakan rasa cinta kepada dunia tersebut. Semakin meningkatnya usia dan pengalaman membaca akan menuntut hadirnya bacaan lain yang lebih tinggi kadarnya. Dengan demikian, posisi chick lit dalam dunia sastra Indonesia memang hanya sebagai sebuah “jembatan” bagi seorang pembaca untuk sampai ke dunia sastra.

\section{Mengapa Chick-lit Laris Manis?}

Sebagaimana sudah diungkapkan bahwa beberapa novel chick lit meraih best seller di pasaran. Apa yang menyebabkan karya-karya tersebut laris manis. Hal itu dapat dilihat sebenarnya dari beberapa segi yang menampilkan perannya masing-masing. Sisi penerbit sebagai fihak yang memang berupaya sekuat tenaga agar buku-bukunya menjadi laris manis adalah dengan mengolah hasil terbitannya dalam bentuk menarik dan mencolok, baik dalam segi kaver dan huruf-huruf di dalamnya. 
Faktor lain yang menjadikan novel-novel ini menjadi laris manis adalah juga dari sistem promosi yang dilakukannya. Nisha, yang berprofesi sebagai penyiar radio misalnya, dengan sangat gencar menggunakan fasilitas radio sebagai corongnya untuk mempromosikan bukunya. Selain itu, dengan dukungan penerbit selain dilakukan launching juga di beberapa kota diadakan jumpa pengarang yang acaranya disusun sedemikian rupa sehingga serupa dengan jumpa artis. Dalam hal penerbit menganut sistem mendekati pembacanya sebagai segmen pasar yang potensial.

Laris manisnya buku ini juga disebabkan kedekatannya dengan dunia film dan selebriti. Untuk dunia film antara karya-karya chick lit dan film saling mempromosikan. Artinya apabila ada novel yang best seller segera difilmkan, kalau ada film yang box office akan segera dibukukan, seperti yang terjadi dalam film "Brownies" yang novelnya ditulis oleh Fira Basuki. Kondisi-kondisi seperti inilah yang ternyata membawa keberuntungan bagi karya-karya jenis ini yang membawa pengarangnya tiba-tiba menjadi kaya raya.

Apa pun karya yang dikelompokkan dalam chick lit dan teen lit tampaknya telah memunculkan pilihan bacaan lain bagi publik pembaca di Indonesia. Ada banyak hal yang akan dapat diperoleh di dalamnya, antara lain juga debat apakah chick lit dapat digolongkan sebagai karya-karya postfeminis atau tidak atau bahkan justru terjebak dalam dunia yang patriakri seutuhnya, apakah karya-karya tersebut dapat dinilai berkualitas sehingga trendnya akan terus berlanjut dan hidup. Perdebatan tersebut tidak akan berhenti selama masih 
dimunculkan karya-karya yang lain. Nisha Rahmanti belum lama ini meluncurkan novelnya yang kedua dengan judul Beauty Case.

\section{PENUTUP}

\section{Simpulan}

Berdasarkan pembahasan, novel-novel tersebut layak diakui sebagai warga sastrIndonesia karena pembaca karya-karya tersebut memang ada dan karya-karya ini cukup populer. Novel-novel yang dikelompokkan sebagai chick lit ditulis oleh perempuan dan ditujukan kepada pembaca perempuan. Oleh karena itu, pembaca novel-novel tersebut memang sebagian besar adalah perempuan, baik perempuan yang sudah matang usianya maupun perempuan-perempuan muda yang dapat digolongkan sebagai pembaca pemula. Novel-novel tersebut mendapat tanggapan yang cukup luas, kesan pertama yang segera muncul dari tanggapan-tanggapan tersebut adalah kesan bahwa karya-karya tersebut digemari karena sifatnya yang "gue banget" atau dalam ungkapan lain adalah karya-karya litersebut dekat dengan kehidupan para perempuan pembaca chick lit. Hal tersebut cenderung terjadi karena karya-karya itu pertama kali diciptakan oleh pengarangnya berdasarkan pengalaman sejati perempuan yang ditulis juga dengan perspektif perempuan. Persoalan yang diajukan juga khas perempuan sehingga perasaan "gue banget" dari 
pembaca memang wajar muncul. Keistimewaan inilah yang menyebabkan karya-karya yang digolongkan sebagai chick lit ini menjadi sangat populer.

Hal tersebut yang menjadi faktor penting mengapa novel-novel chick lit ini laku keras. Pembaca pun tidak merasa kesulitan mendapatkannya karena kini tersedia berbagai sarana, sampai yang tercanggih yaitu media internet yang mau tidak mau membukakan peluang yang lebih besar bagi tersebarnya informasi mengenai bentuk-bentuk dan karyakarya terbaru tersebut. Diskusi mengenai keberadaan karya-karya chick lit dengan mudah tersedia melalui media maya.

Di antara diskusi-diskusi yang dilakukan oleh pembacanya tersebut ada sebuah tanggapan yang cukup menarik. Tanggapan itu adalah adanya keinginan dari pembacanya untuk juga menulis sebuah novel. Fenomena ini menjadi menarik karena ternyata chick lit sebagai sebuah karya sastra ternyata tidak hanya membangkitkan selera pembacanya untuk hanya sekedar membaca, tetapi juga untuk mencipta sebuah karya sastra. Dengan demikian, chick lit sebagai sebuah karya sastra menjadi primadona karena keberadaannya di tengah pembaca perempuan semakin dibutuhkan sebagaai bacaan gaya hidup masa kini.

\section{Saran}

Chick lit merupakan salah satu fenomena terbitan yang masih baru, berbagai hal masih dapat dilaksanakan untuk melengkapi penelitian mengenainya. Bukan hanya aspek pembaca yang dapat dikaji, melainkan aspek-aspek lain masih perlu diperhatikan. Misalnya 
kajian yang mendalam mengenai chick lit karena jenis ini cukup menarik untuk dilakukan mengingat hingga sekarang batas antara karya sastra populer dan karya sastra serius sudah tidak ada lagi. Chick lit sebagai sebuah fenomena akan menarik apabila pembahasan dihubungkan dengan fenomena kebangkitan gender. 


\section{DAFTAR PUSTAKA}

Adji, Charmantha S. 2004. Cinta Kuya. Jakarta: Gagas Media.

Benny chandra.com (diakses 11 Juni 2016)

Emzir. 2008. Metode Penelitian Pendidikan Kuantitatif dan Kualitatif. Jakarta:

Raja Grafindo Persada.

Endah, Albertine. 2005. Cewek Matre. Cetakan Kedua. Jakarta: PT Gramedia Pustaka Utama.

Green, Jane. 2005. Apa Adanya. Alih Bahasa Monica Dwi Chresnayani dari Straight Talking. Jakarta: PT Gramedia Pustaka Utama.

http://sandranarita.blogspot.com/2004 0701 sandranita archive.html (diakses $10 \mathrm{Juni}$ 2016).

http://subjectre.blogspot.com/2004/12/review-from-reader.html (diakses 10 Juni 2016).

http://www.pikiran-rakyat.com/cetak/khazanah/catatanbudaya.htm (diakses 10 Juni 2016).

Jauss, Hans Robert. 1975. "The Idealist Embarrsement Observation of Marxist Aesthetic". Dalam Ralp Cohen (ed.). New Direction in Literary History. London: Roudledge \& Keegan Paul.

Luxemburg, Jan Van. 1989. Tentang Sastra. Terjemahan Akhdiati Ikram. Jakarta: Intermasa-ILDEP.

Naya, Golda. 2005. "Icha Rahmanti, Pengarang Novel Bes Seller Chick Lit Cintapucinno: Terinspirasi Pengalaman Pribadi Plus Riset Internet”. Dalam Indopos, Sabtu 16 April.

Pradopo, Rachmat Djoko. 1986. "Estetika Resepsi dan Teori Penerapannya". Dalam Sulastin Sutrisno dkk. Editor. Bahasa, Sastra, Budaya. Yogyakarta: Gadjah Mada Uiversity Press. 
Presshttp://www.chicklit.us/News4.htm Rahmanti, Icha. 2005. Cintapucinno. Cetakan Kesebelas. Jakarta:Gagas Media.

Rahmanti, Icha. 2005. Cintapucinno. Cetakan Kesebelas. Jakarta:Gagas Media.

Santoso, Satmoko Budi. 2005. "Chick lit dan Teen lit: Realitas Paradigma Kualitatif”. Dalam Mata Baca. Volume 3. No. 8, April.

Seger, Rien T. 1978. The Evaluaation of Literary Texts. Lisse: The Peter de Rider Press.

Utari, F. Dewi Ria. 2005. "Sebuah Jembatan Bernama Chick Lit". Dalam Tempo, 6 Februari. Wordspy.com (diakses 12 Juni 2016).

Wordspy.com (diakses 12 Juni 2016). 